TEME, г. XLIII, бр. 2, април - јун 2019, стр. 395-411

Прегледни рад https://doi.org/10.22190/TEME180326025V

Примљено: 26. 3. 2018.

UDK 373.2:37.014.5

Ревидирана верзија: 14. 1. 2019.

Одобрено за штампу: 17. 4. 2019.

\title{
УМЕТНИЧКЕ ПРАКСЕ У КОНТЕКСТУ \\ НЕОЛИБЕРАЛНИХ ИДЕОЛОГИЈА У ОБРАЗОВНИМ \\ ПОЛИТИКАМА: ПРИМЕР СРПСКОГ ПРЕДШКОЛСКОГ ВАСПИТАЫА И ОБРАЗОВАЫА
}

\author{
Вера Вечански $^{1 *}$, Ана Кузмановић Јовановић ${ }^{2}$ \\ ${ }^{1}$ Универзитет у Београду, Учитељски факултет, Београд, Србија \\ ${ }^{2}$ Универзитет у Београду, Филолошки факултет, Београд, Србија \\ vera.vecanski@uf.bg.ac.rs
}

\begin{abstract}
Апстракт
Циљ овог рада јесте да из перспективе критичке педагогије, која промовише образовање као процес стварања активних и слободних чланова друштва, анализира везу између доминантног савременог политичко-економског система (тзв. неолибералног капитализма) и различитих тенденција у предшколском васпитању и образовању, како глобално тако и у Србији. Указујући на пресудан значај који игра има за когнитивни, емоционални и социјални развој деце, као и на важну везу између игре и учења на предшколском узрасту, анализирамо како идеологија неолибералног капитализма утиче на маргинализацију дечје игре и доводи до академизације и школаризације пракси предшколског васпитања и образовања, уз промоцију компетитивности и конзумеризма од најранијег узраста. Истовремено, нудимо предлоге одређених игроликих ликовних активности - конкретно, ручно прављење играчака - представљених из перспективе интегративног приступа, које могу бити вишеструко корисне у супротстављању поменутим негативним васпитно-образовним тенденцијама: промовишу учење као стваралачки процес, враћају игри централну улогу у предшколском васпитно-образовном програму, представљају отклон од доминантних вредности потрошачке културе. Сматрамо да је такав креативни и активни приступ учењу од најранијег узраста основа за успостављање нове културе учења и, сходно томе, једног другачијег образовног и васпитног система који ће почивати на истински демократским вредностима, а не легитимизовати неолиберални систем и његову идеологију.
\end{abstract}

Кључне речи: предшколско васпитање и образовање, неолиберална идеологија, дечја игра, ликовне активности, ручно прављење играчака. 


\title{
ART PRACTICES IN THE CONTEXT OF NEOLIBERAL IDEOLOGIES IN EDUCATIONAL POLICIES: EXAMPLE OF SERBIAN PRESCHOOL EDUCATION
}

\begin{abstract}
The aim of this paper is to analyze the relationship between the tenets of the dominant contemporary political-economic system (so-called neoliberal capitalism) and various tendencies in preschool education, both globally and in Serbia, from the perspective of critical pedagogy, which promotes education as a process of creating active and free members of society. Pointing to the crucial importance that play has for cognitive, emotional and social development of children, and to important link between play and learning at preschool age, we discuss the impact that the ideology of neoliberal capitalism currently has on the marginalization of children's play, academicization of the preschool system and on the development of competitiveness and consumerism in children from the earliest age. We would therefore like to suggest certain artistic activities for preschoolers resembling the typical children's play, such as the manual making of toys, presented from the perspective of integrative approach. This approach can be useful in many ways in combating negative educational tendencies: it promotes both learning as a creative process and play as central to the preschool education whilst significantly departing from the dominant values of consumer culture. We believe that such a creative and active approach to learning from the young age is the basis for establishing a new culture of learning and, consequently, a different educational system that will rest on true humanistic values rather than on legitimization of the capitalist system and its structure.
\end{abstract}

Key words: $\quad$ preschool education, neoliberal ideology, free play, arts and crafts activities, handmade toys.

\section{УВОД}

Доминантне вредности савременог политичко-економског система утичу на све аспекте институционализованог образовања већ од предшколског узраста. Кроз рану академизацију ${ }^{1}$, развој и доступност дигиталне технологије, маркетинг усмерен ка најмлађима, деца од најранијег узраста бивају васпитавана у специфичној култури снажно обележеној вредностима неолибералног капитализма, у којој ce „образовање (...) прилагођава захтевима капиталистичког тржишта радије него демократским вредностима, а школе репродукују доминантну културу и статус кво у друштву" (Kincheloe 2008, према Groenke \& Hatch, 2009, p. 4). Међутим, сви који учествују у васпитно-

\footnotetext{
${ }^{1}$ Под раном академизацијом подразумевамо тенденцију доминације и инсистирање на подучавању академским знањима и вештинама већ од најранијег узраста, које се најчешће спроводи кроз трансмисију и репродукцију знања на релацији одрасли-дете, без уважавања слободне дечје игре као најприроднијег и развојно најприкладнијег вида учења у овом узрасту (Hirsch-Pasek et al, 2009; Nicolopoulou, 2010).
} 
образовном процесу, како васпитачи, односно учитељи, тако и деца, могу и треба да у васпитно-образовним институцијама свих нивоа заједно раде на промени културе учења и подучавања, као и самих васпитно-образовних институција (Groenke \& Hatch, 2009). Основни предуслов за такву промену јесте учинити децу активном у самом процесу учења, што ће их касније, потенцијално, постепено учинити активним члановима друштва. Промишљање образовних политика и пракси у специфичном друштвеном, политичком, економском и историјском контексту, у циљу њихових усклађивања са демократским вредностима, задатак је и циљ критичке педагогије, која чини теоријски основ овог рада.

\section{Идеологија неолибералног капитализма и предшколско образовање и васпитање}

Јасно је да се образовање не може одвојити од економског развоја, јер, како тврди Епл (Apple), „готово све образовне политике и праксе јесу под снажним утицајем све више интегрисане међународне економије" (Apple, 2011, p. 222). Ова савремена економска парадигма - неолиберални капитализам, настала у другој половини прошлог века, постала је доминантна, хегемона идеологија на глобалном нивоу и тзв. „здрав разум” нашег доба (Harvey, 2005). Иако је неолиберализам „пре свега доктрина политичке економије, то је такође и цивилизацијски принцип који обликује социо-културну структуру кроз социјализацију у најширем значењу" (McGuigan, 2014, p. 224). Ова доктрина почива на идеји да се људско благостање најпотпуније може досегнути уколико се сви сегменти јавног и приватног живота организују по принципу слободног тржишта (Harvey, 2005, p. 2), чије законе представља као природне и свеважеће. Неолиберализам је идеологија која претвара све аспекте наших друштвених и личних живота у такмичење; индивидуални људски живот постаје врста пословног подухвата, а непрестана потреба за личним усавршавањем један од императива савременог човека (Dardot \& Laval, 2014, p. 8).

Важна карактеристика неолибералне доктрине јесте „проширивање процеса компетитивности и комодификације на раније издвојене домене политичког и економског живота" (Brenner, Peck \& Theodore, 2010, p. 329), као што је образовање (Apple, 2011; Bori, 2018) на свим нивоима. Једна од индиректних последица утицаја ове идеологије на образовање јесте претерана и прерана академизација предшколског васпитања и образовања. Целокупан васпитно-образовни систем у савременим западним друштвима ${ }^{2}$ постаје врста при-

\footnotetext{
2 Због специфичних историјских, културних, економских и друштвених околности након Француске револуције и нарочито после Првог светског рата, а посебно због униформишуће снаге глобалног неолибералног економског и
} 
преме за будуће академске и тржишне успехе. Последице таквих образовних политика јесу све већи притисак на децу, родитеље, учитеље и васпитаче, преношење правила тржишне утакмице у сферу васпитања и образовања уз развијање високе компетитивности међу децом и васпитно-образовним установама. Међутим, можда најзначајнија последица ових промена јесте постепен нестанак слободне игре из детињства (Zigler \& Bishop-Josef, 2009).

Уместо да буде основни медиј кроз који деца уче (а о благотворном утицају слободне дечје игре говорили су сви велики педагози у модерној историји), слободна дечја игра ${ }^{3}$ бива замењена академским стандардима и прописаним активностима и садржајима (Johnson, Ersay, Christie, Cohen, Plaster, 2006). Будући да сада већ постоји довољно обимна литература која говори о негативним последицама ових промена по ментално здравље деце (Miller \& Almon, 2009; Nicolopoulou, 2010; Zigler \& Bishop-Josef, 2009), сматрамо да је неопходно непрестано указивати на њих и понудити алтернативе оним образовним политикама које маргинализују дечју игру, усклађене са конкретним васпитно-образовним контекстом.

У овом раду бавимо се специфичном игроликом активношћу за коју сматрамо да може бити вишеструко корисна у борби против негативних васпитно-образовних тенденција у савременим друштвима високо развијеног капитализма и враћању слободне дечје игре у васпитно-образовне институције. Поменута активност јесте ручна израда играчака. Показаћемо како овај вид ликовне активности у контексту предшколског васпитно-образовног програма може представљати адекватан одговор на бројне наведене директне и индиректне последице утицаја неолибералне идеологије на овај сегмент васпитања и образовања: претерану академизацију и школаризацију, увођење неадекватних метода подучавања и провера знања, промовисање компетитивности и нестанак слободне игре из предшколских установа, као и вид отпора комерцијализацији детињства (Kane, 2016).

друштвеног модела проширеног у последњим деценијама 20. века, могуће је говорити о јединственом западном културном и друштвеном простору, којем свакако припада и Србија (в. Кузмановић Јовановић, 2013, p. 9).

${ }^{3}$ Слободна дечја игра је она игра која није иницирана нити посредована од стране одрасле особе, већ спонтана и природна дечја активност. У овом раду под термином „дечја игра” подразумевамо слободну, неструктурирану дечју игру. 


\section{ИДЕОЛОГИЈА НЕОЛИБЕРАЛНОГ КАПИТАЛИЗМА И ПРЕДШКОЛСКО ВАСПИТАҢЕ И ОБРАЗОВАЬЕ КРОЗ ПРИЗМУ КРИТИЧКЕ ПЕДАГОГИЈЕ}

\section{Перспектива и ичиљеви критичке педагогије}

Да бисмо разумели утицај идеологија на образовање, морамо имати у виду да, како тврди Епл, не постоји неутрално знање, већ је оно увек резултат „селективне традиције” (Apple, 2004, p. 6); другим речима, одређена значења и праксе у образовним политикама и курикулумима бивају наглашени, док нека друга значења и праксе бивају занемарени и скривени. Овакво селективно знање у школама увек је одраз интереса и веровања владајуће класе у друштву, због чега школе имају улогу да репродукују хегемону, доминантну идеологију, и на тај начин допринесу одржавању постојећег друштвеноекономског система (Apple, 2004; Giroux, 1997). Као што не постоје неутрално знање и образовање, тако ни педагогија не сме бити неутрална. Она мора указивати на то чије се знање и вредности преносе наредним генерацијама, које друштвене групе поседују моћ, а које су маргинализоване (Apple, 2004, p. хx). Таква, односно критичка педагогија, има за циљ да помогне у преиспитивању и трансформисању постојећег неправедног друштвено-економског поретка кроз формирање прогресивних, критички освећених и активних чланова друштва (Freire, 2016). Њена најважнија улога јесте да помогне трансформацији позиције ученика и едукатора из обичних конзумената образовних политика и програма у активне учеснике у процесу стварања знања (Norton \& Toohey, 2004, p. 1).

\section{Игра, играчке и индустрија играчака}

Из перспективе неолиберализма, данас доминантног система вредности, детињство постаје део припреме за успешно школовање, које пак треба да омогући успешну интеграцију у компетитивно капиталистичко тржиште рада (Groenke \& Hatch, 2009, p. 5). Најважнија последица овог уплива неолибералних идеологија у рано образовање деце јесте потискивање и маргинализација слободне игре. За пионире и класике раног образовања деце, као што су Коменски (Komensky), Русо (Rousseau), Песталоци (Pestalozzi), Штајнер (Steiner), игра је имала централну улогу у дечјем развоју, због чега заузима веома важно место у традиционалној педагошкој и психолошкој литератури. Аутори попут Брунера, Дјуија, Пијажеа, Виготског наводе да је она основни вид учења у раном детињству (Bruner, 1983; Dewey, 2004; Piaget, 1952; Vygotsky, 1966).

Међутим, средином 20. века, услед велике промене у оријентацији предшколског образовања ка оној која се заснива на стандар- 
дима (за детаљну анализу узрока ових промена в. Drew, Christie, Johnson, Meckley \& Nell, 2008; Johnson, Ersay, Christie, Cohen \& Plaster, 2006), игра губи ово централно место у раном образовању деце и постаје нека врста препреке за спровођење нових образовних политика и циљева (Miller \& Almon, 2009, p. 15) ${ }^{4}$.

У овим новим тенденцијама учествује друштво у целини: политичари, родитељи, васпитачи, али и шира научна заједница, чији су резултати неуролошких истраживања о раном развоју мозга често погрешно интерпретирани, па чак и злоупотребљавани (Nicolopoulou, 2010 , p. 1-2). Наиме, константно истицање важности раног подстицаја и учења код деце довело је до настанка одређене атмосфере напетости и потребе за хитним увођењем и интензивирањем директног подучавања на предшколском узрасту (Nicolopoulou, 2010, p. 2). Притисак је не само на родитељима и деци већ и на образовним институцијама, које и саме бивају приморане да нуде разрађене програме, уз увођење стандарда постигнућа и у вртиће и њихово устројавање према законима тржишта. Међутим, прерано и претерано излагање предшколске деце методама учења неадекватним за њихов узраст (директно подучавање, дрил, тестирање и сл.) код њих доводи до различитих психолошких и емотивних проблема, истовремено их претварајући у пасивне и некритичке конзументе готовог знања (Guddemi, Fite \& Selva, 2013). Осим тога, није довољно само подстицати дечји интелектуални и когнитивни развој. Развијање одређених социјално-емоционалних вештина од подједнаког је значаја, а најважније међу њима чији развој подстиче слободна игра јесу саморегулација понашања, пажње и емоција, као и способност и спремност за сарадњу (Nicolopoulou, 2010, p. 3).

Још једна важна последица утицаја идеологије доминантног политичко-економског система јесте и пораст тржишта дечјих едукативних играчака, оних које су осмишљене и направљене са намером да подучавају. Неолиберална логика слободног тржишта, компетитивности и непрестане потребе за личним усавршавањем креира атмосферу у којој родитељи осећају велики притисак да пруже својој деци когнитивни стимулус већ од рођења, па чак и пре тога (Hirsh-

\footnotetext{
${ }^{4}$ Стандарди учења у предшколству (енгл. early learning standards) крајем 20. века су уведени као структурални елемент реформе предшколског образовања у САД (одакле су се прошириле на глобалном нивоу) као моћна полуга за унапређење учења и процене деце предшколског узраста за школску спремност. Међутим, како показују бројна истраживања, међу самим васпитачима расте отпор према покрету стандардизације и академизације раног образовања, будући да су те промене довеле до сужавања образовних циљева и потискивања учења кроз игру у корист више дидактичких облика учења, непримерених предшколском узрасту деце (Drew et al., 2008).
} 
Pasek, Michnick Golinkoff, Berk \& Singer, 2009). Рани когнитивни развој представља се као процес не само одвојен од игре већ и угрожен слободном дечјом игром. Уместо слободне игре, стога, промовише се играње тзв. едукативним играчкама, чија производња је у великој мери одређена тржишним, а не педагошким мотивима.

Индустрија играчака јесте део тзв. „културне индустрије”. Како тврде Хоркхајмер и Адорно, творци овог термина, „културни производи имају исте карактеристике као и остала роба у масовној капиталистичкој производњи: комодификација, стандардизација и масификација" (Horkheimer \& Adorno, 2002 [1944], према Bori, 2018). За разлику од производа који задовољавају наше телесне потребе, културни производи су усмерени на људске мисли (Dant, 2003, p. 110). Дакле, они имају задатак да легитимизују постојећи политичко-економски систем, због чега је њихов утицај на раном, предшколском узрасту дечјег развоја посебно снажан и опасан.

„Протеривање” игре из детињства има, дакле, озбиљне и дубоке негативне последице (Nilsson, Ferholt \& Lecusay, 2017; Митранић, 2016; Zigler \& Bishop-Josef, 2009); без игре, деца немају довољно прилике да се опробају у ситуацијама у којима сама испитују, истражују, ризикују, сазнају, решавају различите проблеме, а које слободна дечја игра омогућава (Miller \& Almon, 2009; Nicolopoulou, 2010; Pavlović Breneselović, 2015). Осим тога, дихотомија између учења и играња је вештачка и погрешна, будући да су играње и учење код деце нераскидиво повезани (Nilssonetal, 2017, p. 2).

Данас постоји значајан корпус истраживања која, након периода омаловажавања и потискивања, враћају игру у центар интересовања педагога (Johnson et al., 2006; Zigler \& Bishop-Josef, 2009). Према постмодерном схватању сложености и динамичности света, детињство се посматра као сложени социо-културни конструкт (Krnjaja i Pavlović Breneselović, 2013) а игра као „комплексни адаптивни систем" како за децу тако и за одрасле (Vander Ven, 2006, p. 409 према Митранић, 2016, p. 412). Игра се, истовремено, из постмодерне перспективе, сагледава као простор деконструкције, преговарања и стварања договора, простор у којем је могуће слободно експериментисати с друштвеним правилима и преиспитивати режиме истине (Krnjaja, 2012), те је стога можемо посматрати и као шире политичко питање остваривања демократије (Freysinger, 2006, према Митранић, 2016, p. 412). Управо овај постмодерни приступ чини игру важним фактором у постизању циљева критичке педагогије, која образовање посматра као поље демократске борбе.

\footnotetext{
${ }^{5}$ У питању је термин који су сковали филозофи Франкфуртске школе Макс Хоркхајмер и Теодор Адорно да означе процес индустријализације културе, до којег долази због комерцијалних императива који управљају капитализмом.
} 


\section{КРЕАЦИЈА И ТРАНСФОРМАЦИЈА: ПОТЕНЦИЈАЛ ЛИКОВНИХ АКТИВНОСТИ У КОНТЕКСТУ ПРЕДШКОЛСКОГ ВАСПИТАҢА И ОБРАЗОВАЬА}

Ликовне активности, које су у средишту нашег интересовања, у савременим васпитно-образовним праксама имају сличну судбину као и сама дечја игра. Наиме, паралелно са дихотомијом између игре као „неозбиљне” и учења као „озбиљне” активности, у предшколском васпитно-образовном програму иста дихотомија постоји између ликовних активности, представљених махом као мање озбиљних, чија је сврха углавном разонода, предах и опуштање, и других „озбиљнијих" активности које се реализују углавном у оквиру образовних области као што су развој говора, упознавање околине, усвајање почетних математичких појмова и слично ${ }^{6}$.

У овом раду настојимо да превазиђемо поменуту дихотомију, те ликовне активности представљамо из перспективе интегративног приступа, који не види уметност само у домену естетског, емоционалног и доживљајног, с чиме се она најчешће доводи у везу, већ у први план истиче њен интегративни и обједињујући карактер и могућност да утиче на готово све аспекте развоја: когнитивни, социоемоционални, физички, развој говора, али и развој маштовитости, креативности и истраживачких способности (Eisner, 1990; ХаџиЈованчић, 2012). Захваљујући холистичкој природи уметности, уметничке (па тако и ликовне) активности поседују изузетан потенцијал за укупан развој деце пружајући им искуство различитих садржаја и омогућавајући им да изражавају своја осећања и размишљања, процесуирају знање које је уграђено у њих и стварају нова значења (Вечански Николић, 2015; Ivić, 2015).

У контексту вртића у Србији, међутим, учење и развој предшколске деце најчешће је организовано унутар засебних предметних области - другим речима, преовладава предметно/дисциплинарно оријентисан курикулум (Baucal, Pavlović Breneselović, Miškeljin, Koruga, Stanić \& Avramović, 2016). Исто тако се и ликовне (као и друге уметничке) активности остварују независно од других активности или пак кроз површну „корелацију” са активностима из других образовних области, где се сазнајни потенцијал ликовних активности углавном своди на површну илустрацију садржаја из других области или се наглашава њихов декоративни и естетски аспект.

\footnotetext{
${ }^{6}$ Ликовне активности у овом раду посматрамо као игролике и блиске слободној игри; иако су делимично структуриране, ипак их не можемо изједначити са уобичајеним дидактичким играма, јер остављају деци велику слободу креативности, коришћења маште и истраживања (Вечански, Васиљевић Благојевић и Маринковић, 2017: 372).
} 
Стога је у контексту праксе предшколског васпитања и образовања у Србији тренутно тешко говорити о искоришћавању пуног потенцијала које ликовне активности по својој природи имају.

Да би ликовне активности заиста могле да делују свеобухватно на развој деце, оне не смеју бити усредсређене само на афективни, естетски и декоративни аспект, већ се центар пажње мора померити и на њихову сазнајну и интегративну функцију. Тиме ликовне активности постају простор дечјег истраживања и активирања односа према сопственом стваралаштву. Услов за то јесте да се осмисле и спроводе тако да омогућавају деци да „слободно истражују и експериментишу без страха од грешке, да имају довољно простора за оригиналне замисли и иницијативе, да негују пре продуктивне него репродуктивне способности" (Хаџи-Јованчић 2012, р. 135-136). Због свог суштинског значаја за когнитивни и друштвено-емоционални развој деце, игра мора бити оквир за спровођење целокупног васпитно-образовног рада, укључујући ту и ликовне активности. У наставку рада представићемо специфичан вид ликовних активности који адекватно интегрише поменуте позитивне аспекте и активира сазнајну функцију ликовних активности спроведених кроз игру. У питању је ручна израда играчака.

\section{Учење као стварање: ручна израда играчака}

Ручна израда играчака је стваралачка манипулативна активност која се заснива на раду с материјалима и употреби материјала, те у себи садржи истраживачки и креативни процес. Ова некада уобичајена активност, којом су се деца и одрасли често заједно бавили, данас је, због доступности индустријски израђених играчака, али и агресивног маркетинга индустрије играчака, помало заборављена и анахрона, упркос многим позитивним ефектима које има (Вечански Николић, 2015, p. 3).

У вртићима код нас ове активности се најчешће одвијају у оквиру ликовних активности, које су у овом узрасту и саме налик игри. Као резултат ових активности, настају различити дводимензионални производи (цртежи, слике, графике итд.) или тродимензионални објекти и предмети који, уколико се потом користе у игри, преузимају на себе улогу играчке. Деца посебно спонтано користе као играчке направљене тродимензионалне предмете (на пример, извајане фигуре аутомобила или лутака). Међутим, чак и цртежи или слике, једноставним интервенцијама, на пример исецањем по контури и причвршћивањем за неки штапић, могу постати реквизити за игру.

Будући да активности у оквиру којих се могу ручно израђивати играчке имају одлике и игре и стварања, као такве оне јачају стваралачке снаге детета, као и његов активни, стваралачки однос према свету, окружењу, животу и самом себи. У питању је вид ак- 
тивности са позитивним ефектима на различите аспекте развоја, као што су креативност и маштовитост, сазнање, развој чула, моторички и физички, социо-емоционални и еколошки аспект (Вечански Николић, 2015). Сви ови позитивни ефекти могу се повезати и са критичком педагогијом, чији је један од основних циљева транформисање културе образовања из репродуктивне и пасивне у активну и стваралачку.

У представљању позитивних ефеката ликовних активности, самим тим и оних у оквиру којих се могу израђивати играчке, посебно ћемо се усредсредити на то како оне подстичу и развијају креативно, стваралачко, функционално и критичко мишљење, како развијају активан однос према окружењу и како омогућавају развој здравих еколошких навика, као отклона од конформистичког мишљења.

\section{Креативност, машта и решавање проблема}

Креативност, као „способност флуентног решавања проблема с оригиналним, иновативним и адекватним решењима" (Guilford, 1967; Amabile, 1989 према Вечански Николић 2015, p. 46), представља концепт који многи савремени теоретичари и педагози сматрају кључним потенцијалом за 21. век, јер све брже промене којима се већ одликује садашњост, а свакако ће се одликовати и будућност, захтевају од појединаца брзо и лако прилагођавање, сналажење и решавање проблема у новонасталим ситуацијама.

Будући да подразумева довођење у везу удаљених и наизглед неповезивих асоцијација, креативност је веома блиска машти, која представља способност замишљања нечега што у датом тренутку није доступно чулима, као и способност употребе реалних чињеница или искустава у осмишљавању и стварању нечег новог (Montesori 2010 [1949], p. 224). Машта, која се кроз ликовне активности веома развија, изузетно је значајна у активном односу према сопственом деловању, јер омогућава да се замисле промене и трансформације које се потом могу остварити.

У сваком стваралачком процесу, па и у ликовним активностима у којима дете израђује играчку, реалност и машта доведени су у непосредну везу; дете своје замисли које је створило у машти креативним и стваралачким чином „доводи”, то јест „преводи” у реалност (Moyles, 1989).

Када израђује играчку (посебно ако је у питању играчка потребна за тачно одређену игру), дете пролази кроз одређени креативни процес: најпре замишља како ће она изгледати, затим осмишљава план како ће је израдити, тражи најадекватнији начин за остваривање своје замисли, експериментише с материјалима и облицима, при чему пролази кроз бројне покушаје и грешке. Крајњи производ мора 
бити функционалан и, често, иновативан, како би служио сврси. Дакле, креативност је у овом процесу израде играчке неодвојива од сазнајног и мисаоног процеса.

\section{Функиионално мишљење у процесу рада с материјалима}

Ликовне активности у предшколском узрасту, па тако и оне у оквиру којих се могу израђивати и играчке, увек подразумевају употребу и манипулисање различитим материјалима. Процес размишљања помоћу материјала и у материјалу, који је овде присутан, неодвојив је елемент ликовних активности и представља процес који Ајзнер (Eisner) назива „размишљање у медију” (Eisner, 2003, p. 343), својствен свим уметничким процесима. Током израде неког ликовног предмета (у овом случају играчке), адекватан одабир материјала је од великог значаја, будући да сваки „материјал поседује одређена својства или особине, различите могућности које се могу истражити и које могу подстаћи или сугерисати нове идеје" (Вечански, 2014, p. 49). Неретко почетне идеје бивају модификоване у самом процесу израде предмета због самих особина коришћеног материјала. Зато само непосредна манипулација материјалима указује на могуће правце у изради финалног предмета. Иако се тај правац неће увек показати успешним, сваки покушај подстакнуће дете на даље промишљање о правим решењима. Овај динамичан процес Шон (Schön) назива размишььање у акиији и размишььање о акиији (Schön, 1983); у њему дете покушава да дође до адекватних одговора и решења управо кроз манипулацију материјалом. Покушаће да испита да ли могућности изабраног материјала омогућавају решење датог проблема или не; како мора да поступи с тим материјалом и на који начин треба да га употреби да би до решења дошло. Другим речима, кроз „размишљање у акцији и размишљање о акцији" деца уче да процењују и вреднују направљено и размишљају о начинима за његово унапређење - уче да критички промишљају и решавају проблеме, а тај процес је додатно подстакнут тиме што се одвија на садржајима, то јест објектима који су за дете посебно релевантни (као што су играчке за децу).

Ликовни процеси омогућавају деци да схвате како предмети настају, да разумеју механизме узрока и последица, али и да увиде и могућности сопственог деловања у циљу њихове промене, побољшања или трансформације у жељеном правцу, што је изузетно важно за развој осећања самопоуздања у погледу сопствене проактивности и активног односа према проблемима и свом окружењу. 


\section{Активан однос према сопственом стваралаштву и проиесу креирања промена}

Поједина истраживања показују да искуства која деца стичу приликом састављања и растављања ствари (а ликовне активности и процеси израде играчака то подразумевају) утичу на самопоуздање детета по питању његових сопствених вештина (Bunker, 1991). Направљена играчка је видљив доказ дечјег стваралаштва и способности, те стога извор задовољства и поноса, нарочито уколико се касније користи у игри. Осим осећања сопствене вредности, она детету доказује да сопственим активним деловањем може направити оно што му је потребно, те тако стварати промене и утицати на своје окружење. Како наводи Брунер, ако дете може да конструише правим објектима, научиће да конструише и идејама (Bruner, 1972). Управо у томе лежи потенцијал ових активности у одгајању деце у духу слободних, активних и креативних чланова друштва.

\section{Еколошки аспект и дух поштовања околине}

Једна од последица неумереног конзумеризма који промовише неолиберални капитализам јесте и огромна штета по животну околину; у овом друштвено-економском поретку ни природа није поштеђена комодификације (Cleaver, 1997; Gonzalez, 2004). Васпитање у духу поштовања, а не експлоатисања природе - важан је елемент агенде критичке педагогије.

Како израда играчака у контексту вртића често подразумева коришћење алтернативних, тј. природних и рециклажних, материјала (лишћа, гранчица, каменчића, односно делова старих играчака или поломљених предмета, картонских кутија, жица, вунице, различитих тканина, пластичних флаша, чепова итд.), деца њиховим коришћењем уместо да стварају нов отпад, трансформишу отпад и дају му нову функцију. Истовремено, кроз процес трансформације већ коришћених материјала, или материјала из природе, деца разумеју како предмети око њих настају, уче да правилно користе ресурсе који су им на располагању и како да се брину о својим стварима (будући да се ручно прављене играчке могу лако поправљати и дорађивати). Не треба занемарити ни здравствене предности ових предмета, пошто се индустријске играчке неретко праве од штетних и опасних материјала (Becker, Edwards \& Massey, 2010), који су јефтинији и профитабилнији. Ручна израда играчака, дакле, није само еколошка активност, већ и помаже деци да развију правилан однос према околини и природним ресурсима. 


\section{ЗАКЉУЧАК}

Игра је несумњиво основни покретач учења код деце и витална снага њиховог физичког, друштвеног, когнитивног и емоционалног развоја (Miller \& Almon, 2009, p. 8). Упркос свим њеним добробитима за целокупан когнитивни, друштвени и емоционални развој деце, савремене глобалне образовне политике инсистирају на дихотомији између игре и учења, док доминантна неолиберална идеологија истовремено намеће потребу за компетитивношћу на свим нивоима образовања. Једна од последица ових тенденција јесте и рана академизација и школаризација предшколског васпитања и образовања, која уводи директно подучавање, тестирање и стандарде постигнућа и у вртиће. Ови процеси су директно подстакнути упливом неолибералне логике слободног тржишта у образовне политике, где се рано стицање одређених академских вештина представља као кључ за успех у даљем школовању, а оно је пак улазница на капиталистичко тржиште рада. У таквом концепту васпитања и образовања, игри има све мање места. Истовремено, око оваквог васпитнообразовног модела ствара се читава индустрија која нуди родитељима и едукаторима своје „културне производе”, претварајући децу у пасивне и некритичке конзументе готовог знања, а касније у исто тако пасивне чланове друштва.

Бројна истраживања указују на алармантне последице искључивања игре из раног детињства и излагања деце неадекватним садржајима и методама учења (појачан стрес, репродуктивно знање уместо продуктивног знања, подстицање потрошачког менталитета итд). Због тога је потребно кориговати владајуће тенденције у предшколском васпитању и образовању и упорно указивати (родитељима, едукаторима, творцима образовних политика) на то да је игра основа когнитивног, друштвеног, емоционалног и физичког развоја код деце.

Ручна израда играчака, као вид делимично структурираних ликовних активности у вртићу, идеална је активност за чулне, сазнајне, когнитивне и друге врсте подстицаја, као и погодно средство учења кроз игру. Не треба занемарити ни еколошки аспект ове активности, будући да се за њу махом користе природни и рециклирани материјали, чиме се деца васпитавају у духу поштовања природе. Све су то важни облици отпора потрошачком друштву: уместо да децу излажемо стресу ране академизације и прилагођавању компетитивности „слободног тржишта”, подстичемо их да буду ствараоци који активно размишљају и решавају проблеме, поштујући друге и околину. Док ручно израђују играчке, деца својим активностима трансформишу саму културу учења, чиме преиспитују доминантне вредности савременог друштвено-економског система, припремају се за активну улогу у друштву, уче се да критички промишљају. 
Као препорука за даља истраживања, сматрамо да је потребно додатно испитати на који начин је игра присутна у српским вртићима, као и анализирати саме ликовне активности у предшколским установама (да ли су третиране холистички и интегрисане са другим активностима, или се одвијају независно од њих, или као њихова илустрација, непотребни вишак и „додатак”). Дакле, важно је испитати и постоји ли, и у којој мери је изражена, дихотомија између игре и учења, односно, када су ликовне активности у питању, дихотомија између уметности као стварања артефаката (лепих, декоративних предмета) и уметности као истраживачког процеса. Све су ово важна питања на које је неопходно дати одговоре како би се могло приступити изради конкретних смерница за постизање циљева наведених у овом раду: укидање дихотомије између игре и учења, укидање дихотомије између уметности као стварања артефаката и уметности као истраживачког процеса, промовисање учења као стваралачког процеса и враћање игри централне улоге у предшколском васпитно-образовном програму. Сматрамо да је креативни и активни приступ учењу од најранијег узраста основа за успостављање нове културе учења и подучавања кроз промоцију стваралачког односа према учењу, као пут васпитања деце у духу слободних, мислећих и активних чланова друштва.

\section{ЛИТЕРАТУРА}

Apple, M. (2004). Ideology and Curriculum ( $3^{\text {rd }}$ edition). Routledge: London/ New York. Apple, M. (2011). Global Crisis, Social Justice and Teacher Education. Journal of Teacher Education, 62(2), 222-234.

Baucal, A., Pavlović Breneselović, D., Miškeljin, L., Koruga, D., Stanić, K. \& Avramović, M. (2016). ECEC in Serbia: situational analysis and recommendations. World Bank.

Becker, M., Edwards, S. \& Massey, R.I. (2010). Toxic Chemicals in Toys and Children's Products: Limitations of Current Responses and Recommendations for Government and Industry. Environmental Science and Technology, 44(21), 7986-7991.

Bori, P. (2018). Language Textbooks in the Era of Neoliberalism. Routledge: London.

Brenner, N., Peck, J. \& Theodore, N. (2010). Variegated Neoliberalization: Geographies, Modalities, Pathways. Global Networks, 10 (2), 182-222.

Bruner, J. (1972). The Nature and Uses of Immaturity. American Psychologists, 27 (8), $687-708$.

Bruner, J. (1983). Play, thought, and language. Peabody Journal of Education, 60(3), 60-69.

Bunker, L. K. (1991). The Role of Play and Motor Skill Development in Building Children's Self-Confidence and Self-Esteem. The Elementary School Journal, 91(5), 467-471.

Cleaver, H. (1997). Nature, Neoliberalism and Sustainable Development: Between Charybdis \& Scylla? Retrieved from https://la.utexas.edu/users/hcleaver/port. $\mathrm{html}, 23.12 .2017$. 
Dant, T. (2003). Critical Social Theory: Culture, Society and Critique. London: Sage.

Dardot, P. \& Laval, C. (2014). The New Way of the World: On Neoliberal Society, London/ New York: Verso.

Dewey, J. (2004 [1916]). Democracy and Education: An Introduction to the Philosophy of Education. New York: Macmillan.

Drew, W. F. Christie, J., Johnson, J.E., Meckley, A.M., \& Nell, M.L. (2008). Constructive Play. A Value-Added Strategy for Meeting Early Learning Standards. Young Children, 63(4), 38-44.

Eisner, E. W. (2003). The Arts and the Creation of Mind. Language Arts, 80(5), 340-344.

Eisner, E. W. (1990). The Role of Art and Play in Children's Cognitive Development. In: Klugman, E. \& Smilansky, S. (Eds.): Children's Play and Learning: Perspectives and Policy Implications (43-58). New York and London: Teachers College Press.

Freire, P. (2016 [1968]). Pedagogia do oprimido [Pedagogy of the Oppressed]. Rio de Janeiro/ São Paulo: Paz \& Terra.

Giroux, H. (1997). Pedagogy and the Politics of Hope: Theory, Culture, and Schooling, A Critical Reader, Boulder, CO: Westview Press

González, C. (2004). Trade Liberalization, Food Security and the Environment: The Neoliberal Threat to Sustainable Rural Development. Retrieved from http://digitalcommons.law.seattleu.edu/cgi/viewcontent.cgi? article $=1385 \&$ context=faculty 22. 12. 2017.

Groenke, S. \& Hatch, J. A. (eds.) (2009). Critical Pedagogy and Teacher Education in Neoliberal Era, New York: Springer.

Guddemi, M., Fite, K. \& Selva, G. (2013). Where is the Play? Current Kindergarten Expectations Unsubstantiated: Findings from Gesell Institute's Study of Preschool Children. IPA-USA e-journal Fall 2013, 6-20.

Harvey, D. (2005). A Brief History of Neoliberalism. Oxford: Oxford University Press.

Hirsch-Pasek, K., Michnick Golinkoff, R., Berk, L., \& Singer, D. G. (2009). A mandate for playschool learning in preschool. Presenting the evidence. Oxford, UK: Oxford University Press.

Ivić, I. (2015). Čovek kao animal symbolicum [The Man as Animal Symbolicum]. Beograd: Zavod za udžbenike.

Johnson, J., Ersay, E., Christie, J., Cohen, L., Plaster, L. (2006). Block play and performance standards: Using unstructured materials to teach academic content. Presentation at the National Association for the Education of Young Children, November 8, 2006. Retreived from http://www.isaeplay.org/Resource_ Articles/Using_Block_Play.pdf 12.1.2018

Kane, N. (2016). The Play-Learning Binary: U.S. Parents' Perceptions on Preschool Play in a Neoliberal Age. Children \& Society, 30(4), 290-301.

Krnjaja, Ž., \& Pavlović, B.D. (2013). Gde stanuje kvalitet, Politika građenja kvaliteta u predškolskom vaspitanju [Where Does Quality Live - Policies of Building Early Childhood Education Quality]. Beograd: Institut za pedagogiju i andragogiju Filozofskog fakulteta Univerziteta u Beogradu.

Krnjaja, Ž. (2012). Igra kao susret - koautorski prostor u zajedničkoj igri dece i odraslih [Playing as Encounter: Co-Authorial Space in Play between Children and Adults] Etnoantropološki problemi, 7(1), 251-267.

Kuzmanović Jovanović, A. (2013). Jezik i rod. Diskursivna konstrukcija rodne ideologije [Language and Gender. Discursive Construction of Gender Ideology]. Beograd: Čigoja štampa.

McGuigan, J. (2014). The Neoliberal Self. Culture Unbound, 6, 223-240.

Miller, E., \&Almon, J. (2009). Crisis in the kindergarten: Why children need to play in school. College Park: Alliance for Childhood. 
Montesori, M. (2010[1949]). Upijajući um [The Absorbent Mind]. Beograd: DN centar. Moyles, J. R. (1989). Just Playing?: Role and Status of Play in Early Childhood Education. Maidenhead, UK: Open University Press.

Nicolopoulou, A. (2010). The Alarming Disappearance of Play from Early Childhood Education.Human Development, 53, 1-4. DOI: 10.1159/000268135

Nilsson, M., Ferholt, B. \& Lecusay, R. (2017). 'The playing-exploring child': Reconceptualizing the relationship between play and learning in early childhood education, Contemporary Issues in Early Childhood, 0(0), 1-15. DOI: 10.1 177/14639491 17710800

Norton, B. \&Toohey, K. (2004). Critical Pedagogies and Language Learning. Cambridge: Cambridge University Press.

Pavlović Breneselović, D. (2015). Gde stanuje kvalitet: Istraživanje sa decom prakse dečjeg vrtića [Where Does Quality Live: Research of Preschool Practices With Children]. Beograd: Institut za pedagoška istraživanja, Filozofski fakultet.

Piaget, J. (1952). The Origins of Intelligence in Children. New York: Basic Books.

Schön, D. (1983). The Reflective Practitioner: How Professionals Think in Action. London: Temple Smith.

Vygotsky, L. S. (1966). Play and Its Role in the Mental Development of the Child. Voprosy psikhologii, 6. Retrieved from https://www.marxists.org/archive/ vygotsky/works/1933/play.html 24.11.2017.

Zigler, E.F. \& Bishop-Joseph S. J. (2009). Play Under Siege: A Historical Overview. Zero to Three, 30(1), 4-11.

Вечански, В., Васиљевић Благојевић, М. и Маринковић, Т. (2017). Развојни потенцијал ликовних активности на предшколском узрасту [The developmental potential of art activities at the preschool age]. Настава $u$ васпитање, 66(2), 367-380.

Вечански Николић, В. (2015). Развојни потенщијал и модалитети коришћења ручно израђених играчака на предиколском узрасту [The developmental potential and usage modalities of handmade toys at preschool age] (необјављена докторска дисертација). Београд: Учитељски факултет Универзитета у Београду.

Вечански, В. (2014). Улога симболичког и експресивног језика уметности у педагошкој концепцији Ређо Емилија [The role of symbolic and expressive language of art in the pedagogical conception of Reggio Emillia], Иноваиије $y$ настави, 27(4), 44-54.

Митранић, Н. (2016). Смернице за подршку дечјој игри [Guidelines for social support to child play]. Настава и васпитање, 65(2), 411-425. DOI: 10.5937/nasvas. $1602411 \mathrm{M}$

Хаџи-Јованчић, Н. (2012). Уметност у општем образовағу: функиије и приступи настави [Art in general education: functions and approaches]. Београд: Учитељски факултет - Klett. 


\title{
ART PRACTICES IN THE CONTEXT OF NEOLIBERAL IDEOLOGIES IN EDUCATIONAL POLICIES: EXAMPLE OF SERBIAN PRESCHOOL EDUCATION
}

\author{
Vera Večanski ${ }^{1}$, Ana Kuzmanović Jovanović ${ }^{2}$ \\ ${ }^{1}$ University of Belgrade, Teacher Education Faculty, Belgrade, Serbia \\ ${ }^{2}$ University of Belgrade, Faculty of Philology, Belgrade, Serbia
}

\begin{abstract}
Summary
This paper analyzes the interplay between the tenets of the dominant global political and economic system (so-called neoliberal capitalism) and various tendencies in preschool education, from the perspective of critical pedagogy that promotes education as a process of creating active and free members of society. Despite numerous research studies confirming the crucial importance of free play for the cognitive, emotional and social development of children, as well as the important link between play and learning at preschool age, the gradual adoption of the neoliberal economic practices in the education domain in the last few decades has been contributing to the marginalization of children's play and has hence led to the academization of the preschool system. Academization of the preschool system implies that the teaching of academic knowledge and skills starts from the very young age. This is most often done through direct teaching, testing and introduction of standards of achievement in kindergartens, with the promotion of competitiveness and consumerism from the young age. This exposure of children to inadequate content and learning methods has extremely negative consequences for their development (increased stress, adopting reproductive rather than productive attitude to acquiring knowledge, fostering consumer mentality, etc.). Since we believe that we need to continue pointing out to parents, educators and creators of educational policies that the play is the basis of cognitive, social, emotional and physical development in children in order to correct these dominant educational trends in preschool education, we have suggested several play-like arts and crafts activities, such as the manual making of toys, which can be useful in many ways in combating these negative educational tendencies. These activities are presented from the perspective of an integrative approach. Namely, producing handmade toys, as a kind of partly structured artistic activity in the kindergarten, is an ideal activity for the stimulation and development of sensory, cognitive and other types of incentives. It is also a suitable way of learning through play which creates a context in which children can be educated in a spirit that promotes environmental awareness and respect for nature. We have shown how this play-like activity promotes learning as a creative process, how it enables the play to acquire the central role in the preschool educational system and finally how it represents a departure from the dominant values of consumer culture. We believe that such a creative and active approach to learning from the earliest age is the basis for establishing a new culture of learning and, consequently, a different education system that will rest on true democratic values rather than on legitimization of the capitalist system and its ideology. As a recommendation for further research, we stressed the need to further examine the role and place of the play, and the treatment of artistic activities in preschool institutions in Serbia, so that concrete guidelines can be developed for achieving the goals stated in this paper: the doing away with play and learning dichotomy, as well as with the opposition between art understood as a process of creating artifacts vs. art understood as a research process, hence promoting learning as a creative process and restoring a central role of play in preschool education system.
\end{abstract}

